\title{
Universiteit
}

Leiden

The Netherlands

\section{Sibilants in Libyco-Berber}

Kossmann, M.G.

\section{Citation}

Kossmann, M. G. (2020). Sibilants in Libyco-Berber. Journal Of The American Oriental Society, 140(4), 875-888. doi:10.7817/jameroriesoci.140.4.0875

Version:

Publisher's Version

License:

Licensed under Article 25fa Copyright Act/Law (Amendment Taverne)

Downloaded from: $\quad$ https://hdl.handle.net/1887/3201169

Note: To cite this publication please use the final published version (if applicable). 


\title{
Sibilants in Libyco-Berber
}

\author{
MAARTEN KOSSMANN \\ LEIDEN UNIVERSITY
}

\begin{abstract}
The second-century BCE Libyco-Berber inscriptions from Dougga (present-day Tunisia) have seven different signs for sibilants. In this article the sibilant system of these inscriptions and of the language they represent is studied in detail. It is shown that the different signs are not just graphemic variants but represent different pronunciations. It is also shown that there is a possibility that the seven signs in fact represent three or four articulations with a length contrast, even though the evidence is very weak. As Proto-Berber has been reconstructed with only three sibilants (+ length opposition), the choice of how to analyze the seven Libyco-Berber sibilant signs has important implications as to how the relationship between Libyco-Berber and Proto-Berber is to be assessed.
\end{abstract}

stridentibus horrida linguis verba ferunt (Corippus, Iohannis, IV.351-52) ${ }^{1}$

\section{INTRODUCTION}

There exists little doubt that the Libyco-Berber inscriptions-a large and heterogeneous group of texts from northern Africa, dating from antiquity - are related to the Berber cultural and linguistic sphere. There is a lot of corollary evidence for this, ranging from the fact that a descendant of the script is still in use by the Tuaregs, who speak a Berber language, to the persistence of the Libyco-Berber onomasticon in tribal names from the Islamic period (cf. Jongeling 1994: xi-xxi). Unfortunately, the inscriptions themselves provide only very restricted linguistic material, consisting mainly of names and functions (Février 1956; Rebuffat 2006). Among these few elements, some can easily be equated with Berber terms, such as gld 'king' (cf. the general Berber term agallid 'king', Naï-Zerrad 2002: 773-74), and the single-letter proclitics $w$ 'son of', $n$ 'of', and $d$ 'and', all of which have exact equivalents in modern Berber. The analysis of most other terms is strongly debated, and although Berber equivalents have been proposed (e.g., Marcy 1936; Rössler 2001a [1958]; Rössler 2001b [1962-1964]; Chaker 1995, 2005), ${ }^{2}$ there is no consensus about this.

Few people therefore doubt a relationship of Libyco-Berber with Berber in general, and even the late Lionel Galand, who was once highly skeptical of Berberocentric interpretations of the texts (e.g., Galand 2002a [1996]), sometimes admitted Libyco-Berber facts when analyzing Berber linguistic history (Galand 2002c [1991], more cautiously 2010: 215).

\footnotetext{
Author's note: This article is dedicated to the memory of Lionel Galand (1920-2017). I wish to thank Jonay Acosta Armas, Ahmad Al-Jallad, Irma Mora Aguiar, Marijn van Putten, Lameen Souag, Benjamin Suchard, and the anonymous reviewer for comments, discussions, and disagreement. Of course, all responsibility for errors and flaws in the argument remains with the author.

1. Quoted after Modéran 2003: chap. 9 n. 106, where the author translates "des mots épouvantables prononcés par leurs langues aux sifflements stridents."

2. Unfortunately, I have not been able to consult Dolgopol'skij 1976 or Militarev 1994, as suggested by the anonymous reviewer.
} 
Considering Libyco-Berber to be part of the Berber sphere does not automatically imply that it is "simply" a Berber language, i.e., that it would have descended from the same protolanguage as that reconstructible on the basis of the modern Berber languages. This is a point made by Louali and Philippson (2004: 114). In their view, Libyco-Berber could have been a sister language of the ancestor of the modern Berber languages rather than a member of the group itself. The little lexical information that we have at our disposal is not very helpful for this question. Elements such as the prepositions $n, d$, or the word $w$-could already have existed on a higher genetic node, while the cultural item gld could easily be a loan from Libyco-Berber into proto-Berber or the other way around. In this article, I will analyze one specific element of the phonological system, sibilants, and discuss the possible implications for the larger question of the relationship of Libyco-Berber to modern Berber languages.

\section{THE ANALYSIS OF THE GRAPHEMIC SYSTEM}

In 1973, Lionel Galand, who maintained a life-long ambivalence as to the interpretation of Libyco-Berber, vacillating between strong skepticism and cautious optimism (Galand 2002d), endeavored to employ the only alternative to lexical comparison in addressing the status of Libyco-Berber: the analysis of the phonemic system as represented in writing (Galand 2002b [1973]). While the question of the relationship of Libyco-Berber to protoBerber may have been irrelevant to his thinking, as he did not accept the notion "proto-Berber" (Galand 2010: 13-14), his type of argumentation is certainly relevant to this purpose.

Libyco-Berber inscriptions are written in various scripts, they are attested over a large area, and they date from different periods (for recent overviews, see Pichler 2007; Springer Bunk 2014; Casajus 2015; Mora Aguiar 2017). Therefore, it does not make much sense to provide a phonological analysis of all Libyco-Berber texts together, as there is no reason to assume that they all represent the same stage and dialects of the language. Instead, it is better to follow Galand's example and focus on the only group of texts that have a clear dating and for which the letter values are largely established. These are the official inscriptions from the city of Dougga in present-day Tunisia (Latin: Thugga; Punic and Libyco-Berber: tbgg), a closely related group of texts using the same script, and different from all other Libyco-Berber inscriptions in that they are written from right to left rather than from bottom to top. Two of these inscriptions are bilingual and contain both a Punic and a Libyco-Berber text. The comparison of the two versions has allowed researchers to establish equivalents between Punic and Libyco-Berber for almost all letters of the Dougga alphabet. Up to now, fourteen texts in the Dougga script have been published. Eleven ${ }^{3}$ were included in Chabot's Recueil d'inscriptions libyques (RIL 1-11), while three more were brought to light by Mansour Ghaki (Ghaki 1997, 2002, 2009; Rebuffat 2013). ${ }^{4}$ Three texts are short fragments that contain only one or two words; the others contain up to fifty-two orthographical words $(R I L$ 2). RIL 2 is dated to $138 \mathrm{BCE}$, and the other texts are probably from roughly the same period (Février 1964-1965: 85).

The script used in the Dougga inscriptions is similar to that in vertical inscriptions from the same region, but it contains a number of letters that are absent in the latter (Pichler 2007: 69).

3. Following Chabot (1940), the fragments RIL 8 and RIL 8bis are counted as a single text, although I do not know the reasons behind this numeration.

4. In addition, Ghaki (2012-2013) has announced the find of a further inscription from Dougga consisting of eight lines of Libyco-Berber text and one line of Punic text, as yet unpublished. 
The letters and their equivalents in Punic are provided in Table One below. ${ }^{5}$ In the transcription and analysis I basically follow Galand (similarly Casajus 2015: 73), with some adaptations. ${ }^{6}$ Chabot (1940), ${ }^{7}$ Rössler (2001a [1958]), Pichler (2007: 47, 69, 73), and Kerr (2010: 54) use different conventions, which are given for the sake of reference.

Table One

\begin{tabular}{|c|c|c|c|c|c|c|}
\hline & $\begin{array}{c}\text { Punic } \\
\text { equivalent }\end{array}$ & $\begin{array}{l}\text { transcription } \\
\text { given here }\end{array}$ & Chabot $^{8}$ & Rössler & Pichler & Kerr \\
\hline 又 & $\mathrm{p} / \mathrm{f}^{9}$ & $\mathrm{p}$ & $\mathrm{F}$ & $\mathrm{p}$ & $\mathrm{p} / \mathrm{f}$ & $\mathrm{f}$ \\
\hline$\odot$ & $\mathrm{b}$ & $\mathrm{b}$ & B & $\mathrm{b}$ & $\mathrm{b}$ & $\mathrm{b}$ \\
\hline $\mathrm{X},+$ & $\mathrm{t}$ & $t$ & $\mathrm{~T}$ & $\mathrm{t}$ & $t$ & $t_{1}$ \\
\hline ] & $t^{10}$ & $t^{3}$ & $\mathrm{~T}_{1}$ & $\mathrm{t}$ & $\begin{array}{l}\text { no tran- } \\
\text { scription } \\
\text { proposed }\end{array}$ & $t_{2}$ \\
\hline$\Pi$ & $\mathrm{d}$ & $\mathrm{d}$ & $\mathrm{D}$ & $\mathrm{d}$ & $\mathrm{d}$ & $d$ \\
\hline 7 & $t$ & $\mathrm{t}$ & $T$ & $t$ & $t$ & $t$ \\
\hline 8 & $\mathrm{~s}$ & $\mathrm{~s}^{1}$ & $\mathrm{~S}$ & $\mathrm{~s}$ & $\mathrm{~s}_{2}$ & $\mathrm{~s}_{1}$ \\
\hline$C, \sqsubset$ & $\mathrm{s}$ & $s^{2}$ & $\mathrm{~S}$ & $\grave{s}$ & $\mathrm{~s}_{1}$ & not included \\
\hline 3 & $\check{s}$ & $\check{s}$ & $\check{S}$ & ś & $\mathrm{s}_{3}$ & $\mathrm{~s}_{3}$ \\
\hline- & $\mathrm{z}$ & $\mathrm{z}^{1}$ & Z & $\mathrm{z}$ & $\mathrm{z}_{2}$ & $z_{3}$ \\
\hline$H$ & $\mathrm{z}$ & $\mathrm{z}^{2}$ & $\mathrm{Z}$ & $\underline{\mathrm{d}}$ & $\mathrm{z}_{1}$ & $\mathrm{z}_{2}$ \\
\hline$m$ & $\mathrm{z}$ & $z^{3}$ & $\dot{Z}$ & $\dot{z}$ & $z_{3}$ & $z_{1}$ \\
\hline$\vdash$ & ș & ș & Ç & $\underline{s}$ & $\mathrm{~s}_{4}$ & $\mathrm{~s}_{2}$ \\
\hline$\leqslant, \leq$ & $\mathrm{k}$ & $\mathrm{k}$ & $\mathrm{K}$ & $\mathrm{k}$ & $\mathrm{k}$ & $\mathrm{k}$ \\
\hline$\tau,\ulcorner$ & $\mathrm{g}$ & $\mathrm{g}$ & G & $\mathrm{g}$ & $\mathrm{g}$ & $\mathrm{g}$ \\
\hline
\end{tabular}

5. The sign $<4>$, which only occurs in the word bnypš $4(R I L ~ 2,1.6)$, is not included in the table. Note that Ghaki (2012-2013: 3) cites the word BNYPST (probably bnypšt) from a hitherto unpublished inscription discovered in 2012. Ghaki's transcription does not specify the difference between $t, t^{3}$, and $t$.

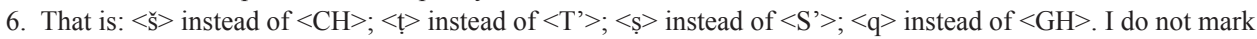
those different letter shapes that are clearly graphemic variants, i.e. $\mathrm{T}^{1}$ vs. $\mathrm{T}^{2} ; \mathrm{K}^{1}$ vs. $\mathrm{K}^{2}$; or $\mathrm{G}^{1}$ vs. $\mathrm{G}^{2}$.

7. Chaker (2005) follows Chabot's conventions, except that he substitutes Chabot's $<\mathrm{T}_{1}>$ by $<\mathrm{t}^{1}>$ and $<$ Ç $>$ by $<$ ș $>$.

8. It is important to note that Chabot's choice of transcription for the voiceless sibilants is based on the Punic equivalents. However, his transcriptions $\left\langle\mathrm{Z}>,\left\langle\mathrm{Z}>\right.\right.$, and $<\dot{\mathrm{Z}}>$ are arbitrary; there is no reason to consider $z^{2}(\mathrm{Z})$ an emphatic consonant, and, for example, Galand suggests "avec beaucoup d'hésitation" an interpretation as $\check{z}$ (Galand 1997: 50).

9. According to Krahmalkov (2001), both $p$ and $f$ were possible realizations of this phoneme in the Punic represented in Plautus's Poenulus. In view of the highly complicated history of the Punic text in this play—parts of which were taken from an older source in Greek, while other parts may present later insertions or adapted transcriptions (for a recent overview, see Rosół 2012) — the implications of these spellings for second-century BCE pronunciations are difficult to assess. According to Krahmalkov, in Neo-Punic "the realization [f] is normative" (Krahmalkov 2001: 24).

10. The reading $\langle t\rangle$ is based on the equivalence of Libyan ypmtt ${ }^{3}$ and Punic ypmtt (twice in RIL 1). Van Putten (2017) calls this reading into question, pointing to Libyan $w d \check{s} t r$ corresponding to Punic 'bdštrt. He suggests an alternative interpretation - without committing to it - as a marker of a final vowel. 
Table One, continued

\begin{tabular}{|c|c|c|c|c|c|c|}
\hline & $\begin{array}{c}\text { Punic } \\
\text { equivalent }\end{array}$ & $\begin{array}{c}\text { transcription } \\
\text { given here }\end{array}$ & Chabot & Rössler & Pichler & Kerr \\
\hline$\div$ & $\mathrm{q}^{11}$ & $\mathrm{q}$ & $\mathrm{Q}$ & $\mathrm{q}$ & $\mathrm{q}$ & $\mathrm{q}$ \\
\hline$\sqsupset, ~ \supset$ & $\mathrm{m}$ & $\mathrm{m}$ & $\mathrm{M}$ & $\mathrm{m}$ & $\mathrm{m}$ & $\mathrm{m}$ \\
\hline $\mathrm{I}$ & $\mathrm{n}$ & $\mathrm{n}$ & $\mathrm{N}$ & $\mathrm{n}$ & $\mathrm{n}$ & $\mathrm{n}$ \\
\hline$\|$ & $\mathrm{l}$ & $\mathrm{l}$ & $\mathrm{L}$ & $\mathrm{l}$ & $\mathrm{l}$ & $\mathrm{l}$ \\
\hline $\mathrm{O}$ & $\mathrm{r}$ & $\mathrm{r}$ & $\mathrm{R}$ & $\mathrm{r}$ & $\mathrm{r}$ & $\mathrm{r}$ \\
\hline$\sim$ & $\mathrm{y}$ & $\mathrm{y}$ & $\mathrm{I}$ & $\mathrm{y}$ & $\mathrm{y}$ & $\mathrm{y}$ \\
\hline$=$ & $\mathrm{w}$ & $\mathrm{W}$ & $\mathrm{U}$ & $\mathrm{w}$ & $\mathrm{w}$ & $\mathrm{w}$ \\
\hline$\equiv$ & & $?$ & $\mathrm{H}$ & $?$ & ? & $\mathrm{V}$ \\
\hline
\end{tabular}

In his comparison of the Libyco-Berber and Berber systems, Galand points to a number of structural similarities. ${ }^{12}$ While Galand remains somewhat vague about how he interprets the results of his comparison of the Dougga system and Berber phonological systems, other scholars are more outspoken, and consider the two to be highly similar, e.g., Chaker (1984: 275) and Casajus (2015: 45-46). Most prominent among these similarities are:

1 ) the presence of only two labial stops (or fricatives), and 2) the presence of no more and no fewer than two emphatic sounds (excluding $<\mathrm{q}>$ from the equation, which Galand does not count as an emphatic).

The presence of only two labial stops (or fricatives) provides a clear parallel to reconstructible Berber. Even though Kossmann (1999: 249) reconstructs a triple opposition /f/ $/ \mathrm{b} /-/ \beta /$, there is only very scanty evidence for $* \mathrm{~b}$ versus $* \beta$, and a slightly more audacious reconstruction could easily do away with the opposition. Of course, this feature is hardly a decisive argument in favor of a Berber link, as two-way systems are well attested in Afroasiatic (among others, in Semitic), and elsewhere in African languages (cf. Maddieson 2013).

The presence of two emphatic sounds is hardly a convincing parallel between LibycoBerber and proto-Berber either. In the first place, the Punic script distinguishes only two emphatic sounds, $<\mathrm{t}>$ and $<\mathrm{s}>$; thus, a further emphatic sound could easily hide behind one of the Libyco-Berber letters corresponding to Punic $<_{\mathrm{S}}>$ or $<\mathrm{z}>$.

The interpretation of $<\mathrm{s}>$ is especially problematic. ${ }^{13}$ It is far from certain that in Punic the sound written by the letter $<$ s $>$ was merely [s] with some kind of special "emphatic" articulation (pharyngealization or some kind of glottalization). It may very well have been affricated as some scholars have argued (cf. Friedrich and Röllig ${ }^{3}$ 1999: 26; Krahmalkov 2001: 24). In the latter case, the choice of the Punic equivalent $<$ s $>$ to Libyco-Berber $<$ s $>$ could have been triggered by a similarity in assibilation and not by the emphatic quality of the sound. Thus, there is little to argue in favor of an interpretation of Libyan $<\mathrm{s}>$ as emphatic $\left(\left[\mathrm{s}^{\mathrm{S}}\right]\right.$ or $\left.\left[\mathrm{s}^{\prime}\right]\right)$ rather than, for example, non-emphatic $[\check{c}]$ or $\left[\mathrm{t}^{\mathrm{s}}\right]$. Moreover, as Jonge-

11. There is no immediate equivalent of Punic $\langle q\rangle$ to this letter, as the only name with $\langle q\rangle$ in a bilingual inscription, Punic $m q l^{2}$, is broken off in the Libyan text (RIL 2). In view of the Libyco-Berber name $m q l^{3} / m q l t^{3}$ in RIL 3, Chabot's interpretation - accepted by all scholars in the field - is undoubtedly correct.

12. I refrain from a discussion of the phonetic aspects in Galand's discussion, as neither the pronunciation of the Libyco-Berber letters nor the exact phonetic makeup of an earlier Berber system is evident.

13. I do not understand Kerr's position that the consonant would not be attested in the bilingual texts and is therefore difficult to interpret (Kerr 2010: 57-58). It does appear, for example, in the Libyco-Berber title mșs kw (RIL 2, 1. 3), which is parallel to Punic mșșky (RIL 2, 1. 9). 
ling (1994: 132) has pointed out, Latin renderings of the Libyco-Berber name șdn suggest that $<$ s $>$ was an affricate, cf. siddin, tziddin, and stiddin (see below); similar transcriptions are found in Latin renderings of Neo-Punic $<$ ș $>$ (Krahmalkov 2001: 24; Kerr 2013: 20-21). All in all, the evidence is ambiguous in the case of the emphatic consonants, and Galand's interpretation is less compelling than it may look at first sight.

\section{THE SIBILANTS}

As noted by Galand, the situation with sibilants looks very different from modern Berber (Galand 2002b [1973]: 34-35). Most Berber languages nowadays distinguish /s/, /š/, /ș/ and /z/, /̌̌/, /z/, that is, six sibilants. Among these, /ș/ is either a loan phoneme from Arabic or an assimilated variant of /z/. Moreover, as shown in Kossmann (1999: 219-35), there is hardly any evidence for an ancient opposition between /s/, /z/ vs. / /s/, /̌̌/. Thus, the most probable reconstruction for proto-Berber has only three sibilants, ${ }^{*} \mathrm{~s},{ }^{*} \mathrm{z},{ }^{*} \mathrm{z}$ (Prasse 2015: 6484).

There are a few Berber varieties that present complications to this reconstruction. In the first place, in Zenaga of Mauritania the regular correspondent to northern Berber /s/ is [S], while the regular correspondent to $/ \mathrm{z} /$ is $\left[\theta^{\mathrm{q}}\right]$. There are two correspondents to northern Berber $/ \mathrm{z} /$ : $[\theta]$ and [3] (non-strident), both corresponding to [z:] when geminated. Before velars, a further realization, [z], is found (Taine-Cheikh 2008: 1xxiii-lxxiv). In the present language the presence of $[\theta]$ and [3] is unconditioned, and they thus represent different phonemes. There are, however, major tendencies as to their distribution, which suggests that the opposition is the result of a phonemic split and is therefore a Zenaga innovation. The consonant $[\theta]$ is mostly found in three contexts: before $/ \mathrm{r} /$, when followed by a vowel followed by $g$ or $\gamma$, and when followed by a vowel followed by long /s:/. In other circumstances, it is mostly [3] that appears.

In the second place, in the Berber variety of Awjila in eastern Libya there are two sets of correspondents to northern Berber /s/ and /z/: $s / \bar{s}$ and $z / z ̌$, respectively. As shown by van Putten (2014: 265-68), there is no clear conditioning to this distribution; he therefore suggests that Awjila may have retained a contrast lost elsewhere. As van Putten himself concedes, this analysis is flawed by the presence of variation within the same root, and, for the time being, the Awjila situation does not seem to present major counterevidence to the reconstruction of just three sibilants in proto-Berber.

It should be noted that the choice of symbols for the reconstructed phonemes ${ }^{*} \mathrm{~s},{ }^{*} \mathrm{z},{ }^{*} \mathrm{z}$ is purely conventional; in view of the Zenaga and Awjila reflexes, one should remain agnostic about their phonetic realization in proto-Berber.

The difference between this reconstructed three-way system and Libyco-Berber is evident. In the Dougga writing system, four ${ }^{14}$ Punic consonants, $\left.<\mathrm{s}>,<\breve{\mathrm{s}}\right\rangle,<\mathrm{s}>,<\mathrm{Z}>$, correspond to seven Libyan consonants, that is, four more than reconstructible for proto-Berber.

In order to assess this problem, it is necessary to show that the different consonant signs in Dougga represent different pronunciations and are not just orthographical variants. In fact, Chabot seems to have favored the latter interpretation for the two signs corresponding to Punic $<\mathrm{s}>$, and subsumes $<_{\mathrm{S}}{ }^{1}>(\mathrm{Z})$ and $<_{\mathrm{S}}{ }^{2}>(\mathrm{C})$ under a single transcription sign. Kerr (2010: 55) suggests that $<\mathrm{z}^{3}>(\mathrm{m})$ is a graphemic variant, and a similar point of view may be behind the absence of $\left\langle\mathrm{s}^{2}>(\mathrm{C})\right.$ in his script table.

In order to argue that the signs designate different phonemes (or at least pronunciations) in the spoken Libyco-Berber language, one ideally wants to have three pieces of evidence:

14. Some authors assume a merger of $s$ and $\breve{s}$ in Punic, which would leave us with only three phonemes expressed by four signs (e.g., Krahmalkov 2001: 25); see however Kerr 2013 for a discussion and an alternative interpretation. 
a) the signs co-occur in the same inscriptions, b) the signs are used consistently in different attestations of the same word or name, and c) there is no obvious conditioning for their occurrence. In order to check this, all the instances of the seven sibilants in the Dougga horizontal inscriptions were collected. In the case of RIL 1 to 11 , I have based myself on the Libyan texts as provided by Chabot, while in the case of the three inscriptions published by Ghaki, I have used the photographs in addition to the transcriptions of the editor. ${ }^{15}$

We can look at the attestations across the inscriptions in Table Two.

Table Two

\begin{tabular}{|c|c|c|c|c|c|c|c|}
\hline & $s^{1}(8)$ & $\mathrm{s}^{2}(\mathrm{C})$ & $\check{s}(3)$ & $\mathrm{z}^{1}(-)$ & $z^{2}(H)$ & $z^{3}(m)$ & ș $(\vdash)$ \\
\hline RIL 1 & $\begin{array}{l}k s^{2} \ln s^{1} \\
m s^{1} d l \\
n n f s^{1} n\end{array}$ & $\begin{array}{l}w r s^{2} k n \\
w-w r s^{2} k n \\
k s^{2} l n s^{1}\end{array}$ & $\begin{array}{l}{[w-] d r \check{s}} \\
w-w d \check{s} t r \\
n-\check{s} q r^{?} \\
w-\check{s} y \\
\check{s} p t\end{array}$ & $n-z^{1} l^{?}$ & & $z^{3} z^{3} y$ & \\
\hline RIL 2 & $\begin{array}{l}m s^{1} n s^{1} n \\
w-z^{1} l l s^{1} n \\
s^{1} y s^{1 ?} \\
m k w s^{1} n \\
m w s^{1} n^{?} \\
w-m s^{1} n p\end{array}$ & $\begin{array}{l}s^{2} b s^{2} n d^{?} \\
s^{2} g d t^{3} \quad 16 \\
w-s^{2} d y l n\end{array}$ & $\begin{array}{l}\text { bnypšs }<?> \\
s \check{p t} 3 \mathrm{x} \\
d-\check{s} p t \\
w-\check{s} p t \\
w-p \check{s} n \\
\check{s} n k \\
w-\check{s} n k 2 \mathrm{x} \\
w-\check{s} m n 2 \mathrm{x} \\
\text { šyn } \\
w \text {-šyn } \\
w-p t \grave{s} \\
w-y r s ̌ t n\end{array}$ & $\begin{array}{l}w-z^{1} l l s^{1} n \\
z^{1} m r\end{array}$ & $g z^{2} b$ & & $\begin{array}{l}s k[n] \\
m s s s k w \\
g l d m s ̦ k\end{array}$ \\
\hline RIL 3 & $\begin{array}{l}w-k n p s^{1} n \\
m w s^{1} n t^{3} \\
5 \mathrm{x}\end{array}$ & $\begin{array}{l}s^{2} d y \ln \\
w-[k] n s^{2} l n \\
m s^{2} b l\end{array}$ & $\begin{array}{l}\check{s} p t \text { t } 2 \mathrm{x} \\
w-p \check{s} n \\
\check{s} m n \\
w-s ̌ m n ~ 2 \mathrm{x} \\
\check{s} y n \\
w \text {-šyn } \\
w \text {-yrštn } \\
w \text {-ršs }\end{array}$ & $\begin{array}{l}d-b n m z^{1} b k^{?} \\
z^{1} m r \\
w-m z^{1} d k^{?}\end{array}$ & $g z^{2} b t^{3}$ & $b z^{3} n$ & $\begin{array}{l}m s ̦ s w w t^{3} \\
\text { gldmșkt }\end{array}$ \\
\hline RIL 4 & & $w-m s^{2} b l$ & & $w-k n z^{1} d t^{3}$ & & & $m s s ̦ k w t^{3}$ \\
\hline
\end{tabular}

15. Ghaki does not provide tracings of the inscriptions, and his transcription systems only reflect part of the graphemic distinctions. Unfortunately, I was unable to establish the reading of all the sibilants in Ghaki 2002. For this text, I only include instances where I could make out the letter on the photograph or where Ghaki's transcriptions are unambiguous, as with $\breve{s}$ and ș. I had to leave out one instance of knsl (1.3) and two instances of mwsnt (11. 3 and 4).

16. Chabot (1940: 3) gives $s^{2} g d t^{3}$ in Libyan script, but transcribes GLDT1. His earlier articles on the inscription have $s^{2} g d t^{3}$ without further comment (Chabot 1918: 269, 273; 1921: 69). The fact that he does not explain his transcription GLDT1 suggests that it is a simple lapsus in the edition. Different authors choose either one of these interpretations, without discussing their choices. Rössler (2001b [1962-1964]), Prasse (1972: 159), and Galand (2002a [1996]) have $s^{2} g d t^{3}$, while Chaker (2005) and Casajus (2015: 42) read $g l d t^{3}$. As far as I can see from photographs, $s^{2} g d t^{3}$ seems to be the correct reading. 


\begin{tabular}{|c|c|c|c|c|c|c|c|}
\hline RIL 5 & ]$s^{1}$ & $\begin{array}{l}m s^{2} b l \\
k n s^{2} l n\end{array}$ & $\begin{array}{l}w-\check{s} p t \\
m \check{s}[\end{array}$ & $w-k n z^{1} d t^{3}$ & $g z^{2} b t^{317}$ & & $m s \underline{s} k w t^{3}$ \\
\hline RIL 6 & $\begin{array}{l}w-m s^{1}[w] \\
\operatorname{pr}[n]\end{array}$ & {$[n] p s^{2} \ln$} & $\begin{array}{l}J b s_{s} w \check{s}^{?} \\
b r s ̌ l k \\
w-\check{s} y[n] \\
\check{s} n n\end{array}$ & & & & \\
\hline RIL 7 & $\begin{array}{l}w-k n s^{1} w n \\
l w s^{1} 2 \mathrm{x}\end{array}$ & $\begin{array}{l}k n s^{2} \ln \\
w-k[n] s^{2} \ln \end{array}$ & $\begin{array}{l}\text { šmn } 5 \mathrm{x} \\
n \text {-šmn } \\
w \text {-šyn } 2 \mathrm{x}\end{array}$ & $w-z^{1} m r 2 \mathrm{x}$ & & $b z^{3} n 2 \mathrm{x}$ & \\
\hline RIL 8 & & & ]$\check{s} d b y[$ & & & & \\
\hline RIL 10 & $m w s^{1} n 2 \mathrm{x}$ & & $\begin{array}{l}p \check{s}[ \\
\check{s} m n \\
\check{s} p t\end{array}$ & $z^{1} m[r]$ & $g z^{2} b$ & $b z^{3} n$ & $\begin{array}{l}m s ̦ s+k w \\
\text { gldmșk }\end{array}$ \\
\hline RIL 11 & $\begin{array}{l}m w s^{1} n t^{3} \\
4 \mathrm{x} \\
w-k n p s^{1} n\end{array}$ & $\begin{array}{l}m s^{2} b l \\
\text { (maybe } \\
\text { a second } \\
\text { attestation) } \\
w-[k n] s^{2} l n\end{array}$ & $\begin{array}{l}p \check{s} n \\
\check{s} m n \\
w \text {-šnk }\end{array}$ & $w-[] z^{1} r$ & $g z^{2} b t^{3}$ & & $\begin{array}{l}m s ̦ s w w t^{3} \\
\text { gldmșkt }\end{array}$ \\
\hline $\begin{array}{l}\text { Ghaki } \\
1997\end{array}$ & $m w s^{1} n t^{3}$ & & & & & & \\
\hline $\begin{array}{l}\text { Ghaki } \\
2002\end{array}$ & $\begin{array}{l}m w s^{1} n t^{3} \\
2 \mathrm{x} \\
y s^{1} l t^{3} 18 \\
m s^{1} l t^{3}\end{array}$ & & $\begin{array}{l}\check{s} p t \underline{2 \mathrm{x}} \\
\check{s} m n\end{array}$ & $k n z^{1} d t^{3} 2 \mathrm{x}$ & $g z^{2} b t^{3}$ & & $\begin{array}{l}m s ̦ s w w t^{3} \\
\text { gld } m s t^{3}\end{array}$ \\
\hline $\begin{array}{l}\text { Ghaki } \\
2009\end{array}$ & $\begin{array}{l}m w s^{1} n t^{3} 2 \mathrm{x} \\
m s s^{1} k y t^{3}\end{array}$ & & & $\begin{array}{l}w-k n z^{1} b n y \\
w-z^{1} w r[ \\
w-k n z^{1}\end{array}$ & $g z^{2} b t^{3}$ & $k n z^{3} r t^{3}$ & $\begin{array}{l}m s s^{1} k y t^{3} \\
g l d m s \underline{k} t^{3}\end{array}$ \\
\hline
\end{tabular}

Let us look at what these attestations tell us with regard to the three types of evidence presented above.

\section{a) Co-occurrence}

Table Two shows that the different sibilant signs are attested all across the inscriptions. In one inscription, RIL 3, all seven sibilant signs are attested. This clearly shows that the choice of the letter signs is not due to different conventions in different texts.

\section{b) Consistency within words}

Many of the names and words are attested several times. The letter choice is highly consistent among these forms:

$$
\begin{aligned}
& \mathrm{s}^{1}(\mathrm{Z}) \mathrm{knps}^{1} \mathrm{2x} \\
& l w s^{1} \quad 2 \mathrm{x} \\
& m w s^{1} n, m w s^{1} n^{2}, m w s^{1} n t^{3} \quad 17 \mathrm{x}
\end{aligned}
$$

17. In view of the unusual place of this term in the series of functions and the poor physical state of the inscription, Février (1964-1965: 88) expresses his doubts about the reading $g z^{2} b t^{3}$ here (RIL 5, 1. 1).

18. One wonders whether $y s^{1} l t^{3}$ in 1.7 should be read $m s^{1} l t^{3}$ as in 1.9 . 


\begin{tabular}{|c|c|c|}
\hline \multirow[t]{4}{*}{$s^{2}(C)$} & $k n s^{2} l n$ & $4 \mathrm{x}$ \\
\hline & $m s^{2} b l$ & $4 \mathrm{x}$ \\
\hline & $s^{2} d y \ln$ & $2 \mathrm{x}$ \\
\hline & $w r s^{2} k n$ & $2 \mathrm{x}$ \\
\hline \multirow[t]{6}{*}{$\check{s}(3)$} & $p \check{s} n$ & $3 x$ \\
\hline & $s ̌ m n$ & $14 x$ \\
\hline & šnk & $4 \mathrm{x}$ \\
\hline & $\check{s} p t$ & $12 x$ \\
\hline & šyn & $7 x$ \\
\hline & $y r \check{s} t n$ & $2 \mathrm{x}$ \\
\hline \multirow[t]{2}{*}{$\mathrm{z}^{1}(-)$} & $k n z^{1} d t^{3}$ & $4 \mathrm{x}$ \\
\hline & $z^{1} m r$ & $5 x$ \\
\hline$z^{2}(\mapsto)$ & $g z^{2} b, g z^{2} b t^{3}$ & $7 x$ \\
\hline$z^{3}(m)$ & $b z^{3} n$ & $4 \mathrm{x}$ \\
\hline \multirow[t]{2}{*}{ ș $(\vdash)$} & gldmșk, gldmșkt ${ }^{3}$ & $6 x$ \\
\hline & $m s \underline{s} k w, m s \underline{s} k w t^{3}$ & $6 x$ \\
\hline
\end{tabular}

There is one word that shows variation. In Ghaki (2009: 1. 7) one finds a title $m s s^{1} k y t^{3}$. This is very similar to the well-attested form $m s s s k w\left(t^{3}\right)$, and it is logical to consider them one and the same title, as assumed by the editor of the inscription (Ghaki 2009: 41). One remarks that not only the second sibilant is different, but also the semivowel ( $y$ instead of $w$ ).

With this one exception, the spelling of names and words is highly regular. Even though some of the signs are less common than others, their use is entirely consistent within words and names.

\section{c) Conditioned variation}

Writing systems often offer conditioned variants depending on the place of the sign in the word; moreover, conditioned phonetic variants can be represented by different signs. In the case of the seven sibilants, there is nothing that points to graphemic conditioning, as shown in Table Three. ${ }^{19}$

Table Three

\begin{tabular}{|l|l|l|l|}
\hline & word-initial & \multicolumn{1}{|c|}{ word-medial } & word-final \\
\hline $\mathrm{s}^{1}(\mathrm{Z})$ & + & + & + \\
\hline $\mathrm{s}^{2}(\mathrm{C})$ & + & + & - \\
\hline$\check{\mathrm{s}}(3)$ & + & + & + \\
\hline $\mathrm{z}^{1}(-)$ & + & + & - \\
\hline $\mathrm{z}^{2}(\mapsto)$ & - & + & - \\
\hline $\mathrm{z}^{3}(\mathrm{~m})$ & + & + & - \\
\hline $\mathrm{s}(\vdash)$ & + & + & - \\
\hline
\end{tabular}

With the exception of $z^{2}$, which is only attested in the word $g z^{2} b\left(t^{3}\right)$, all sibilants are attested both in word-initial and in word-medial position. In word-final position, we find only two sibilants, which may be due to the restricted corpus, and to the specific makeup of

19. As we are dealing with graphemic representations, sibilants in names preceded by the proclitics $w$ - and $d$ are considered to be word-medial. 
many Libyan names, which tend to end in a small number of consonants (cf. Jongeling 1994: xiv-xxi). In any case, the general attestation of the different sibilant signs in word-initial and word-medial position makes an analysis as orthographic variants all but impossible (pace Kerr 2010: 55), even though some of the sibilants are only attested in very few words.

From this analysis, it should be clear that the seven sibilant signs in the Dougga alphabet probably mark different pronunciations in the language. This does not, of course, automatically imply that all these consonants were also present in earlier forms of Libyco-Berber. There is no doubt that the language and culture of the Dougga inscriptions were heavily influenced by Punic (Février 1956), so one could easily imagine Punic influence on the consonant system.

The most conspicuous place to look for such influence is the letter $<\breve{\mathrm{S}}>$. This letter is commonly found in Libyco-Berber words and names with a Punic background, e.g., špt 'a dignitary; personal name' and a number of personal names such as šmn (Punic 'bd'šmn), $r \check{s}$ (Punic ' $r \check{s}$ ), and wdštr (Punic 'bďstrt). On the other hand, a number of names with $<\breve{s}>$ clearly belong to Libyan name types, such as yrštn (Jongeling 1994: xv). There is, therefore, in spite of the frequency of Punic loans with $\langle\breve{s}>$, little reason to consider it a loan phoneme in Libyco-Berber.

\section{THE ANALYSIS OF THE SIBILANT SYSTEM}

All in all, we are thus confronted with seven pronunciations in Libyco-Berber as opposed to only three reconstructible sibilants in proto-Berber. ${ }^{20}$ This is not necessarily an insurmountable problem. Berber - like many other Afroasiatic languages - has an opposition between long ("tense," "geminated") consonants and short consonants. In many cases, this is purely an opposition of length, but in other cases the basic pronunciation of the single consonant changes when it is lengthened. Thus, in most Berber languages, short $[\mathrm{\gamma}]$ corresponds to long [q:], showing a difference in length, closure, and voicing. One way to interpret the seven sibilants of Libyco-Berber is to consider them two sets of three consonants opposed in length, with an additional seventh consonant; one may assume that there were additional phonetic differences between the two sets.

If one assumes that in Libyco-Berber, as in modern Ghadames and Tuareg (Kossmann 2011: 14; 2013: 13), ${ }^{21}$ consonantal length only appeared in word-medial positions, this would explain the presence of only two sibilants in word-final position. The case for word-initial position is a bit more complicated, as all seven sibilant signs appear at the beginning of the orthographic word. This, again, need not constitute a major problem, as Libyco-Berber does not indicate initial vowels. This is easily shown on the basis of Libyco-Berber and Punic equivalents in names: In a number of cases, Punic has an initial aleph, no doubt indicating an initial vowel, ${ }^{22}$ whereas the Libyan text has no marking, e.g., Punic $w$-'nkn vs. LibycoBerber $n k n$ (RIL 1, 1. 6); Punic `šyn vs. Libyco-Berber šyn (RIL 2, 11. 5 and 11), and no doubt Punic ${ }^{2} p \check{s}_{n}(R I L 2,1.4)$ vs. Libyco-Berber $p \check{n} n(R I L$ 11, 1. 4). At least some of these names are

20. Note that it is impossible to equate some of the Libyco-Berber sibilant signs with the $* \mathrm{k}^{\mathrm{y}}$ and $* \mathrm{~g}^{\mathrm{y}}$ reconstructed in Kossmann 1999. In the well-attested term $g l d\left(t^{3}\right)$ 'king', Libyco-Berber $<\mathrm{g}>$ corresponds to * $\mathrm{g}^{\mathrm{y}}$.

21. Most northern Berber languages allow for long consonants in word-initial position, however.

22. Ahmad Al-Jallad (p.c.) points to an alternative explanation according to which Libyco-Berber word-initial consonant clusters would have been pronounced with an extra initial vowel in Punic. The evidence from Latin transcriptions of Libyan names suggests that word-initial consonant clusters were very rare in Libyco-Berber. In Jongeling's (1994) list of well over 2500 names, only about fifty start in a consonant cluster. This includes names with a Punic background, as well as about twenty cases with initial $s t, t s$, or $t z$, which probably transcribe affricated $<$ s $>$. 
Libyco-Berber in origin (cf. Jongeling 1994: xiv on $\left.{ }^{2} p s ̌ n / p s ̌ n ~ a n d ~ x v i i ~ o n ~ ' n k n / n k n\right),{ }^{23}$ so the orthographic convention of not writing initial vowels seems to be well established. Thus, one could assume that the presence of long consonant signs at the beginning of an orthographic word would point to an initial vowel.

If one follows this lead, one may ask which signs would stand for short consonants and which for long consonants. Following up on the assumption that long consonants appear only in word-medial position, any sign appearing in word-final position should be considered short. Moreover, initial signs belonging to words that have no initial aleph in their Punic equivalent would also be unambiguously short. This would be the case of $s^{1}, \check{s}, z^{1}$, and $z^{3}$ :

$\mathrm{s}^{1}(\mathrm{Z})$ Attested in final position: $k s^{1} \ln s^{1}(R I L 1,1.5)$.

š (3) Attested in final position: [w-]dřs (RIL 1, 1. 2); w-řs (RIL 3, 1. 9) (both Punic names).

Certain in initial position: šnk (RIL 2, 1. 8, corresponding to Punic šnk).

$\mathrm{z}^{1}(-)$ Certain in initial position: $z^{1} m r(R I L 2,1.10$, corresponding to Punic $z m r, 1.4)$.

$z^{3}(m)$ Certain in initial position: $z^{3} z^{3} y(R I L 1,1.5$, corresponding to Punic $z z y)$.

The three other signs are not attested in word-final position and have no instances where the (graphemic) word-initial attestations could not be interpreted as being preceded by a word-initial vowel: $s^{2}(C), z^{2}(\mapsto)$, or $s(\vdash)$. These would then, potentially, correspond to long consonants.

As mentioned above, having different signs for long and short sibilants and not for other consonants suggests that there were phonetic differences in addition to length alone. In most modern Berber languages, sibilants are among the consonants that do not have such differences, and the long ("tense," "geminated") equivalent of [s] is simply [s:]. There are a number of exceptions to this. Thus, in Kabyle (Algeria; cf. Basset and Picard 1948: 124) and in Figuig (Morocco; cf. Kossmann 1997: 36-40), some of the long equivalents to sibilants are affricated. This is mainly the case in imperfective formations of verbs with a sibilant as their second consonant, e.g., Figuig Aorist $f s a$, Imperfective $f \partial t t^{s} a$ 'to prepare wool for weav-

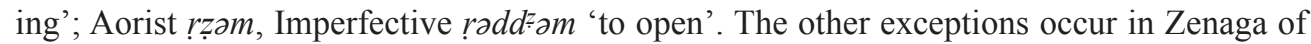
Mauritania (Taine-Cheikh 2001-2003; 2008) and the closely related Tetserret language from Niger (Lux 2013: 112-15, 132-36):
Zenaga:
$\left[\int\right] \quad$ vs. [s:]
$[\theta],[3]$ vs. [z:]
$\left[\theta^{\mathrm{C}}\right] \quad$ vs. $\left[\mathrm{z}^{\mathrm{S}}:\right]$
Tetserret [S] vs. [s:]
[3] Vs. [Z:]
$\left[\mathrm{s}^{\mathrm{\varsigma}}\right]$ vs. $\left[\mathrm{s}^{\mathrm{\varsigma}}:\right]\left(\right.$ rarely $\left.\left[\mathrm{Z}^{\mathrm{\varsigma}}:\right]\right)$

Thus, even though the large majority of modern Berber languages have no further phonetic changes for long sibilants, such a situation is attested at different places and with different systems. There is no reason to assume that such a system could not have existed in Libyco-Berber.

One may object that evidence from other inscriptions presents major problems, at least for interpreting $<\mathrm{s}>$ as a long consonant. As mentioned above, $<\mathrm{s}>$ is found in the name $s d n$ attested on ten gravestones from the extreme northeast of Algeria. Jongeling (1994: 132) convincingly identifies this name with one attested in Latin inscriptions as siddin, tziddin, stiddin, ziddinus (etc.). This would mean that $<\mathrm{s}>$ could indeed appear in initial position and that the absence of proof for this in Dougga is simply accidental. It should be noted,

23. The name nican (accusative) as found in Corippus (Jongeling 1994: 113) is hardly an argument against the presence of an initial vowel, as this attestation dates from nearly seven centuries after the Dougga inscriptions were composed. 
however, that the Dougga alphabet has more sibilant letters than the vertical inscriptions, and that therefore the initial $<\mathbf{s}>$ in $s \underline{d n}$ may correspond to one of the extra signs in Dougga rather than to $<\mathrm{s}>$.

Some authors have suggested that in Libyco-Berber consonantal length was sometimes indicated by means of double writing. This is mainly based on the spellings tbgg (LibycoBerber and Punic) and Libyco-Berber gyy, Punic $g^{c} y y$, corresponding to Latin Thugga 'Dougga' and Greek $\Gamma \alpha l \alpha,{ }^{24}$ respectively (Galand 2002a [1996]: 16, followed by Chaker 2005: 5). As Galand remarks, this is hardly a more elegant solution than other proposals, such as provided by Rössler (2001b [1962-1964]: 483) for tbgg, ${ }^{25}$ and one may add that the spelling convention would be far from regular, assuming that Libyan $\operatorname{gld}\left(t^{3}\right)$ ' king', with one single $l$ grapheme, represents a form similar to modern Berber agallid. Of course, if one accepts that long consonants can be represented by double writing, the case for long sibilants being expressed by special signs is weakened considerably.

All in all, an interpretation of the seven-way distinction in Libyco-Berber as a three-way distinction + length and an additional consonant cannot be ruled out. The case for it is, however, extremely weak. In the argumentation above, the identification of the four short consonants was made on the basis of only six words. This means that the absence of evidence for a short pronunciation with the three other signs may very well be accidental.

Summarizing, the seven Libyco-Berber graphemes can be interpreted in two ways:

1) Libyco-Berber had two sets of three sibilants, related to an opposition in consonantal length. In addition, there was a fourth sibilant for which the length opposition was not indicated by a separate grapheme.

2) Libyco-Berber had seven different short sibilants. The absence of some of them in certain positions is due to chance-something entirely conceivable with the small corpus that we are working with.

Of course, intermediate analyses are also possible, e.g., two sibilants with different graphemes for the length opposition and three additional sibilants where this opposition is not indicated.

\section{CONCLUSION}

In the introduction to this article, the uncertain relationship of Libyco-Berber to protoBerber was pointed out. Generally speaking, there are two possibilities:

1. Libyco-Berber belongs to the same group as modern Berber languages. This means that the reconstructible ancestor of modern Berber languages, i.e., proto-Berber, is also the ancestor of Libyco-Berber. If one follows Louali and Philippson (2004) in putting the date of proto-Berber in the first half of the first millennium $\mathrm{BCE},{ }^{26}$ the time span between proto-

24. This is from the dedication by Massinissa on the Greek island of Delos (Dittenberger ${ }^{3} 1917$, no. 652). There is no doubt about the identity of the names, as both RIL 2 and the Delos inscription refer to the father of Massinissa. Livy gives the name of this same person as Gala, which has been considered a corruption from Gaia since Homolle (1881: 71); cf. Dittenberger ${ }^{3} 1917$ : 212; Chabot 1918: 272; Rössler 2001b [1962-1964]: 483.

25. The situation with the name gyy is complicated by the fact that it has a medial 'ayin in the Punic rendering ( $g$ 'yy). Rössler (2001b [1962-1964]: 483) considers this a transcription of the Libyan vowel, which is problematic, as medial vowels are not written by means of matres lectionis in Punic renderings of Libyan names elsewhere in the Dougga inscriptions. Furthermore, note that in Livy's Latin forms, the final - $a$ (instead of -ay?) could be due to its integration into the Latin declension system (cf. genitive Galae, accusative Galam; Jongeling 1994: 48); this is not the case of Greek $\Gamma \alpha l \alpha$, however, as the name is attested as a genitive ( $\beta \alpha \sigma i \lambda \varepsilon \omega \varsigma \gamma \alpha 1 \alpha$ '(son) of king Gaia'), which should be ${ }^{* *} \Gamma \alpha \iota \alpha \varsigma$ had it been integrated into Greek nominal morphology. In Libyco-Berber inscriptions from outside Dougga both gyy and $g y^{\text {? }}$ occur (Chabot 1940: xviii).

26. Similarly, Blažek (2010), using calibrated lexicostatistics, dates proto-Berber to 680 BCE. 
Berber and attested Libyco-Berber would be relatively short, and one would expect the two to be fairly similar.

2. Libyco-Berber and proto-Berber were two sister languages, ultimately connected at a higher genetic node, whose time depth can only be the object of speculation. In this case, there is no reason to expect a high degree of similarity.

The analysis of the sibilant system leads to ambiguous results: In one analysis, a threeway system in proto-Berber would correspond to a four-way system in Libyco-Berber. This does not seem to present insurmountable problems to the idea that Libyco-Berber descends from proto-Berber exactly like any of the modern Berber languages; one has to concede, however, that the evidence for this analysis is extremely weak.

In the other analysis, Libyco-Berber had seven different sibilant positions. Unless one dramatically changes one's reconstructions, ${ }^{27}$ this is so different from proto-Berber that they can hardly be part of the same group. In this case Louali and Philippson's sister-language approach should be preferred.

\section{REFERENCES}

Basset, André, and André Picard. 1948. Éléments de grammaire berbère (Kabylie-Irjen). Algiers: Éditions "La Typo-Litho" \& Jules Carbonel.

Blažek, Václav. 2010. On the Classification of Berber. Folia Orientalia 47: 245-66.

Casajus, Dominique. 2015. L'alphabet touareg. Paris: Éditions du CNRS.

Chabot, Jean-Baptiste. 1918. Punica (fin). Journal Asiatique, 11th ser., 12: 249-302.

-1921. Mélanges épigraphiques. Journal Asiatique, 11th ser., 17: 76-96.

1940. Recueil des inscriptions libyques. Paris: Imprimerie Nationale.

Chaker, Salem. 1984. Textes en linguistique berbère (Introduction au domaine berbère). Marseille: Éditions du CNRS.

-1995. Terminologie libyque des titres et fonctions. In idem, Linguistique berbère: Études de syntaxe et de diachronie. Pp. 171-92. Louvain: Peeters.

- 2005. Retour à un grand classique libyque: RIL 2, la dédicace à Massinissa. In Studi berberi e mediterranei: Miscellanea offerta in onore di Luigi Serra, ed. Anna Maria di Tolla. Pp. 3-18. Naples: Centro di Studi Magrebini.

Dittenberger, Wilhelm. ${ }^{3}$ 1917. Sylloge inscriptionum graecarum II. Leipzig: Hirzel.

Dolgopol'skij, Aron B. 1976. Numidijskoe (vostočnolivijskoe) piśmo Severnoj Afriki. In Tajny drevnix piśmen-Problemy dešifrovki, ed. Igor M. Ďjakonov. Pp. 384-443. Moscow: Progress.

Février, James. 1956. Que savons-nous du libyque? Revue Africaine 100: 262-73.

—.1964-1965. La constitution municipale de Dougga à l'époque numide. In Mélanges de Carthage offerts à Charles Saumagne, Louis Poinssot, Maurice Pinard. Pp. 85-91. Paris: Guethner.

Friedrich, Johannes, and Wolfgang Röllig. ${ }^{3}$ 1999. Phönizisch-punische Grammatik. Rome: Pontificium Institutum Biblicum.

Galand, Lionel. 1997. Inscriptions libyques du Constantinois (Fonds H.-G. Pflaum). Antiquités Africaines 33: 49-65.

- 2002a [1996]. Du berbère au libyque: Une remontée difficile. In idem, Études de linguistique berbère. Pp. 3-28. Louvain: Peeters.

—. 2002b [1973]. L'alphabet libyque de Dougga. In idem, Études de linguistique berbère. Pp. 29-36. Louvain: Peeters.

-2002c [1991]. L'indication des titres et des fonctions en libyque. In idem, Études de linguistique berbère. Pp. 37-47. Louvain: Peeters.

. 2002d. Interrogations sur le libyque. Antiquités Africaines 38: 259-66.

27. If one assumes that the seven-way distinction was present in proto-Berber, this would mean that it collapsed independently into the same three-way opposition in the different Berber languages. 
. 2010. Regards sur le berbère. Milan: Centro Studi Camito-Semitici.

Ghaki, Mansour. 1997. Épigraphie libyque et punique à Dougga (TBGG). In Dougga (Thugga): Études épigraphiques, ed. Mustapha Khanoussi and Louis Maurin. Pp. 27-45. Paris: De Boccard.

- 2002. Stèles libyques et néopuniques de Tunisie. In L'Africa romana: Lo spazio marittimo del Mediterraneo occidentale. Atti del 14. Convegno di Studio, 7-10 dicembre 2000, Sassari, Italia, vol. 3, ed. Mustapha Khanoussi, Paola Ruggeri, and Cinzia Vismora. Pp. 1661-78. Rome: Carocci.

- 2009. Une nouvelle inscription libyque 'officielle' à Dougga. In "Parcours berbères": Mélanges offerts à Paulette Galand-Pernet et Lionel Galand pour leur $90^{e}$ anniversaire, ed. Amina Mettouchi. Pp. 39-44. Cologne: Rüdiger Köppe.

- 2012-2013. Inscriptions libyques de Tunisie: État de la question. Épigraphie Libyco-Berbère: La lettre du RILB 18/19: 2-4.

Homolle, Jean-Théophile. 1881. Rapport sur une mission à Délos. Archives des Missions Scientifiques et Littéraires, 3rd ser., 7: 65-72.

Jongeling, Karel. 1994. North-African Names from Latin Sources. Leiden: CNWS.

Kerr, Robert M. 2010. Some Thoughts on the Origin of the Libyco-Berber Alphabet. In Études berbères V: Essais sur des variations dialectales et autres articles, ed. Harry Stroomer, Maarten Kossmann, Dymitr Ibriszimow, and Rainer Vossen. Pp. 41-68. Cologne: Rüdiger Köppe.

- 2013. Phoenician-Punic: The View Backward-Phonology Versus Paleography. In Linguistic Studies in Phoenician in Memory of J. Brian Peckham, ed. Robert D. Holmstedt and Aaron Schade. Pp. 9-29. Winona Lake, IN: Eisenbrauns.

Kossmann, Maarten. 1997. Grammaire du parler berbère de Figuig (Maroc oriental). Louvain: Peeters.

—. 1999. Essai sur la phonologie du proto-berbère. Cologne: Rüdiger Köppe.

- 2011. A Grammar of Ayer Tuareg (Niger). Cologne: Rüdiger Köppe.

- 2013. A Grammatical Sketch of Ghadames Berber (Libya). Cologne: Rüdiger Köppe.

Krahmalkov, Charles R. 2001. A Phoenician-Punic Grammar. Leiden: Brill.

Louali, Naïma, and Gérard Philippson. 2004. Berber Expansion into and within North-West Africa: A Linguistic Contribution. Afrika und Übersee 87: 105-30.

Lux, Cécile. 2013. Le tetserret, langue berbère du Niger: Description phonétique, phonologique et morphologique dans une perspective comparative. Cologne: Rüdiger Köppe.

Maddieson, Ian. 2013. Voicing and Gaps in Plosive Systems. In The World Atlas of Language Structures Online, ed. Matthew S. Dryer and Martin Haspelmath. Leipzig: Max Planck Institute for Evolutionary Anthropology.

Marcy, Georges. 1936. Les inscriptions libyques bilingues de l'Afrique du Nord. Paris: Imprimerie Nationale.

Militarev, Aleksander Ju. 1994. Glazami lingvista: Garamantida v kontekste severoafrikanskoj istorii. In Garamantida (afrikanskaja Atlantida), ed. Ju. M. Kobiščanov and A. Ju. Militarev. Pp. 230-82. Moscow: Vostočnaja literatura.

Modéran, Yves. 2003. Les Maures et l'Afrique romaine (IVe-VIIe siècle). Rome: Publications de l'École française de Rome.

Mora Aguiar, Irma. 2017. Influencias e innovaciones gráficas en la creación del alfabeto líbico oriental (Túnez y Argelia). Vegueta: Anuario de la Facultad de Geografia e Historia de la Universidad de Las Palmas de Gran Canaria 17: 493-513.

Naï-Zerrad, Kamal. 2002. Dictionnaire des racines berbères (formes attestées), vol. 3: D-GEY. Louvain: Peeters.

Pichler, Werner. 2007. Origin and Development of the Libyco-Berber Script. Cologne: Rüdiger Köppe. Prasse, Karl-G. 1972. Manuel de grammaire touarègue (tăhăggart), vol. 1: I-III: Phonétique-Écriture-Pronom. Copenhagen: Éditions de l'Université de Copenhague.

- 2015. Protoberbère: Esquisse de phonologie et de morphologie. In Encyclopédie berbère, vol. 38. Pp. 6481-99. Louvain: Peeters.

van Putten, Marijn. 2014. Some Notes on the Historical Consonantism of Awjila. Folia Orientalia 51: $257-74$. 
2017. Are Libyco-Berber Horizontal $t$ and Vertical $h$ the Same Sign? In To the Madbar and Back Again: Studies in the Languages, Archaeology, and Cultures of Arabia Dedicated to Michael C. A. Macdonald, ed. Laïla Nehmé and Ahmad Al-Jallad. Pp. 346-57. Leiden: Brill.

Rebuffat, René. 2006. Aires sémantiques des principaux mots libyques. Mélanges de l'École française de Rome: Antiquité 118: 267-95.

- 2013. Recueil des inscriptions libyques 1940-2012: Supplément à J.-B. Chabot, Recueil des inscriptions libyques, Paris 1940. https://halshs.archives-ouvertes.fr/halshs-00841800/document.

Rosół, Rafał. 2012. Zum Monolog des Hanno im plautinischen "Poenulus" (v. 930-960). Hermes 140: 89-95.

Rössler, Otto. 2001a [1958]. Die Sprache Numidiens. In idem, Gesammelte Schriften zur Semitohamitistik. Pp. 392-418. Münster: Ugarit Verlag.

_ 2001b [1962-1964]. Numidische Inschriften. In idem, Gesammelte Schriften zur Semitohamitistik. Pp. 476-88. Münster: Ugarit Verlag.

Springer Bunk, Renata Ana. 2014. Die libysch-berberischen Inschriften der Kanarischen Inseln in ihrem Felsbildkontext. Cologne: Rüdiger Köppe.

Taine-Cheikh, Catherine. 2001-2003. La corrélation de gémination consonantique en zénaga (berbère de Mauritanie). Comptes rendus du G.L.E.C.S. 24: 5-66.

2008. Dictionnaire zénaga-français. Cologne: Rüdiger Köppe. 
Copyright of Journal of the American Oriental Society is the property of American Oriental Society and its content may not be copied or emailed to multiple sites or posted to a listserv without the copyright holder's express written permission. However, users may print, download, or email articles for individual use. 